\title{
Macrozoobentos Distribution as a Bioindicator of Water Quality in the Upstream of the Citarum River
}

\author{
Nurul Chazanah"*, Barti Setiani Muntalif', Rijki Aulia Rahmayani', Priana Sudjono'1 \\ 1 Faculty of Civil and Environmental Engineering, Bandung Institute of Technology, Indonesia \\ * Corresponding author's e-mail: nurul.chaza@yahoo.com
}

\begin{abstract}
This study aims to prove the type and abundance of macrozoobenthos are affected by the physico-chemical condition of the habitat so that it can be used as a bioindicator in assessing river water quality with a case study in the Upstream of Citarum River. The method used in this study consists of two stages, namely determining the status of river quality with pollution index and determining the components to see the relationship of the water quality parameters to the abundance of macrozoobenthos with principal component analysis. On the basis of these studies, the results were that at the location of the study status of the river quality is slightly polluted and mildly polluted. For the slightly polluted status Corbicula $s p$. was used as the dominant macrozoobenthos parameter with the parameters of dissolved oxygen, organic carbon and $\mathrm{N}-\mathrm{O}$ in the clay-dominated sediments. In turn, for the river areas with mild pollution, Enallagma sp., Tubifex sp., and Chironomous sp. were used as bioindicators and they have a relationship with the parameters of nitrate, TSS, and P-total.
\end{abstract}

Keywords: macrozoobenthos, river water quality, bioindicator

\section{INTRODUCTION}

River is a water ecosystem with a quality that can be influenced by various anthropogenic factors. The interactions in the river ecosystems change due to the human activities in water flow, among others, in the form of making embankments, riverbed dredging and lake, winding environmental straightening and intensive land use both for agricultural, livestock and domestic activities. Therefore, these activities cause changes in the river water quality (Cha et al. 2009), by providing a number of energy and food sources in the form of organic matter and nutrients (Ormerod 2003, Filoso 2011).

The Citarum River is a strategic river utilized for various human activities and is one of the largest rivers in Java with a length of $1078.22 \mathrm{~km}$ and an area of watershed (DAS) $11,323.34 \mathrm{~km}^{2}$ or $32.01 \%$ of the area of West Java Province $\left(35,374.38 \mathrm{~km}^{2}\right)$ certainly needs to be preserved (BBWS 2016). The condition of the quality of the Citarum watershed, which has been polluted, requires good management, so an accurate, fast and relatively inexpensive tool to assess the quality of water I needed.

The assessment of the river water quality that is often performed in Indonesia uses physicochemical parameters in accordance with the Decree of the Minister of Environment No. 115 of 2003, but according to Fore et al. (1993), the measurements of the water quality using the physicochemical parameters in general only reflect the water quality conditions at the moment of sampling, and they could not reflect the quality of the past, while the water pollution continues.

Therefore, in addition to the physico-chemical parameters, bioindicators become one of the parameters that determine the river conditions. Macrozoobenthos is a class of biota that can be used as a bioindicator of the status of a river. According to Pratt and Coller (1976), macrozoobenthos can show specific ecological conditions, whereas according to Li et al. (2009), it has the ability to integrate the effects of short-term environmental changes. 
The biological water quality assessments have long been used, involving macrozoobenthos organisms as bioindicators of a water system. Kolenati (1848) and Cohn (1853) (in Sudarso and Wardianto 2015) observed the relationship between the organisms that live in polluted water in contrast to those living in the water that has not been polluted. The water quality assessment approach used to date consists of a diversity index method, a biotic index, a multinumeric approach, a multivariate approach, functional feeding groups (FFGs), and several biological properties (Li et al. 2009). Several assessments of the water quality with bioindicators in Indonesia have been conducted by previous researchers, among others Muntalif et al. (2008), Kusumaningrum and Bahri (2008), Sudarso and Wardiatno (2015), Wimbaningrum et al. (2016), Chazanah et al. (2017). Geothals and De Pauw (2001) conducted a study in the form of river ecosystem prediction models as environmental factors that influence the bentos communities.

On the basis of the background description, it can be formulated that the assessment of the quality of the existing water currently still relies on the measurement of the physical and chemical parameters, the use of bioindicators has not been developed much, especially for the waters in tropical areas. In tyrn, the use of bioindicators in this case macrozoobenthos can predict the longterm state of waters through the macrozoobenthos distribution model in the aquatic environment.
This research was conducted with the aim of proving the type and abundance of macrozoobenthos are influenced by the physico-chemical conditions of the habitat so that it can be used as a bioindicator of river water pollution status.

\section{METHOD AND MATERIAL}

\section{Study area}

This research is located in the upstream of the Citarum River and covers the areas ranging from the springs to the river flows closest to the anthropogenic activity in the study area. The study was conducted from the period July-September 2019. The selection of the study locations was carried out in five stations starting from the Lake Cisanti outlet, to the river stream in the Tarumajaya Village Settlement, Kertasari Subdistrict, Bandung Regency. The point is chosen based on the environmental baseline and its waste input, for the position of the test point as well as an explanatory description can be seen in Figure 1.

\section{Data Analysis}

\section{Determination of river quality status}

Determination of the water quality status using the pollution index method according to

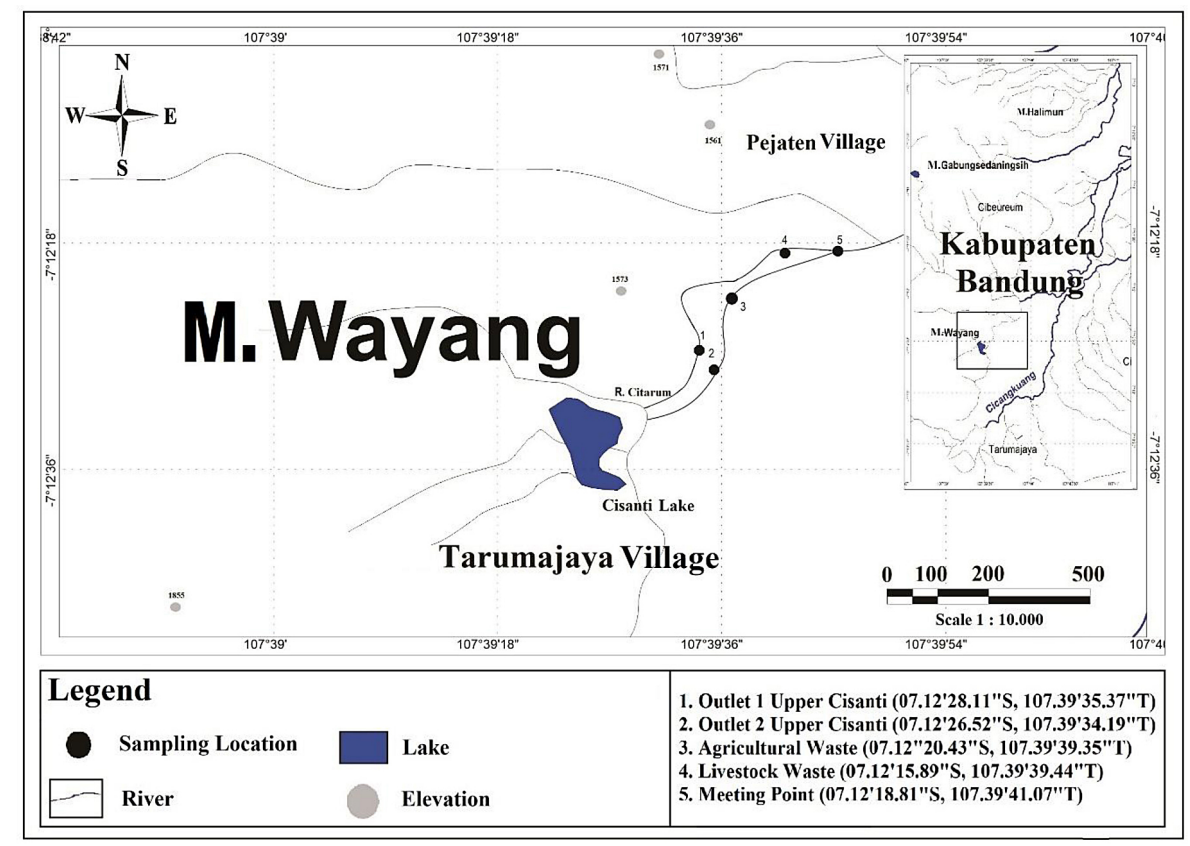

Figure 1. Location of sampling 
KepMenLH 115/2003. The pollution index (IP) method is used to determine the level of pollution relative to the permissible water quality parameters. The analysis of the water quality refers to the river water quality standards according to PP 82/2001, where the quality standards used are class I water quality standards which are designated as drinking raw water. The selection of quality standards is due to the location of the study which is the upstream Citarum River area, which is very close to a spring so that it can be considered that the test site has good water quality.

Determination of the water quality status with pollutant index is carried out by the formula:

$$
I P_{j}=\sqrt{\frac{\left(C_{i} / L_{i j}\right)_{M}^{2}+\left(C_{i} / L_{i j}\right)_{R}^{2}}{2}}
$$

where: $I P_{j}-$ pollution index for designation $j$,

$C_{i}^{j}-$ concentration of water quality parameters $i$,

$L_{i j}$ - concentration of water quality parameters $i$ listed in the water designation standard $j$,

$M$ - maximum,

$R$ - average.

The $I P$ index class consists of 4 with scores:

- $0 \leq I P \leq 1.0$ - meet quality standards,

- $1.0<I P \leq 5.0$ - mildly polluted,

- $5.0<I P \leq 10$ - moderately polluted,

- $I P>10.0$ - heavily polluted.

Determination of the relationship of parameters to macrozoobenthos abundance with statistical analysis

In order to see the relationship between the physico-chemical parameters of aquatic habitat with its macrozoobenthos distribution, the analysis method used was principal component analysis (PCA). PCA is a mathematical method that can distribute the data normally and simplify the complex data in the form of two dimensions, reducing variables so that they can see the parameters affecting the abundance of macrozoobenthos. The PCA analysis was conducted using Minitab Version 17 software.

There are several physico-chemical factors of aquatic habitat that are processed by the PCA method to see the relationship, i.e.: elevation, ammonia, nitrate, nitrite, phosphate, TSS, PH, DHL, DO, depth, speed, C-organic, $\mathrm{c} / \mathrm{n}$, total nitrogen sediment, total $\mathrm{P}$, and texture.
According to Chazanah et al. (2018), the selection of the key physico-chemical and macrozoobenthos parameters can be one of the strategies in the water quality assessment system. The level of macroozobenthos taxa in determining the environmental parameters is the genus because it can describe specific fauna patterns that will be used as bioindicators. There are at least 10 types of macrozoobenthos that are considered dominant against other numbers at each test location used in data processing with PCA, namely Sulcospira sp., Chironomous sp., Simullium sp., Hydropsyche sp., Palaemonetes sp., Libelulla sp., Corbicula sp., Enallagma sp, Anentome sp. and Tubifex $s p$.

The results of the data will then be made in biplot to see the patterns of information from the processed variable. Biplot is a multivariate representation of data in a graphical form that represents the relationship between the columns and rows on a matrix through vectors and points. The interpretation of data in biplots can be seen by paying attention to:

1. Proximity between objects - two objects with the same characteristics will be described as two factors the positions of which are close to each other.

2. Variety of variables with small diversity are described as short vectors, and vice versa.

3. Relationship between variables - if the angle of two variables $<90^{\circ}$ then the correlation is positive; if the angle of two variables $>90^{\circ}$ then the correlation is negative. The smaller the angle, the stronger the correlation.

4. Variable value of an object - the characteristics of an object can be deduced from its relative position closest to a variable.

\section{RESULTS AND DISCUSSION}

\section{Test location quality status}

The measurement of the pollutant index in this study was taken based on the results of the average measurement of water quality for 3 months. Then, the value was compared to class I quality standard. The comparison with class I quality standard was taken based on the measurement value compared to the quality standard in Table 1 could be seen that almost all parameters were still at the threshold of the quality standard of class I. Therefore, the measurements using the 
Table 1. Description of the study area location

\begin{tabular}{|c|l|l|}
\hline Stations & \multicolumn{1}{|c|}{ Location } & \multicolumn{1}{c|}{ Description } \\
\hline Outlet 1 & $\begin{array}{l}\text { Located the flow of the } \\
\text { First Gate of Lake Cisanti }\end{array}$ & $\begin{array}{l}\text { Located in a fairly shady area and covered with trees, surrounded by vegetation } \\
\text { in the form of wild plants with sedimentary conditions dominated by sand and } \\
\text { clay. }\end{array}$ \\
\hline Agricultural waste 2 & $\begin{array}{l}\text { Located in the flow of } \\
\text { the Second Gate of Lake } \\
\text { Cisanti }\end{array}$ & $\begin{array}{l}\text { Located in a brighter area compared to the area around outlet one, around it } \\
\text { there are shrubs and woody plants, with sediment dominated by clay and sand } \\
\text { area }\end{array}$ \\
\hline Animal waste & $\begin{array}{l}\text { Located in the area of } \\
\text { residents' farms }\end{array}$ & $\begin{array}{l}\text { Approximately } 2 \text { km away from outlet 1 with a natural channel which is lower } \\
\text { than outlet one. Being in the middle of agricultural land with horticultural } \\
\text { commodities such as vegetables that are intercropped with coffee plants. With } \\
\text { sediment dominated by sand and clay }\end{array}$ \\
\hline Meeting point & $\begin{array}{l}\text { Located in a residential } \\
\text { area } \\
\text { sand and clay }\end{array}$ & $\begin{array}{l}\text { It is a channel that becomes a flowing meeting between agricultural waste and } \\
\text { livestock waste, located right in the middle of residential areas, there are also } \\
\text { drainage canals from residents' houses that directly enter the water flow. With } \\
\text { sediment dominated by sand and clay }\end{array}$ \\
\hline
\end{tabular}

pollutant index method were taken in class I quality standards.

When viewed in terms of physico-chemical parameters of river water, the outlet 1 and 2 test points are under a condition that still meets the grade I quality standard, while for the agricultural exhaust point, animal husbandry, and the meeting point is under mildly polluted conditions. Overall, it can be said that the conditions at the test location are still quite good.

The difference in determining the quality status of the river can be caused by the presence of the anthropogenic activity around the test site. In terms of agriculture there is the influence of fertilization which is then carried over to the river body, for the animal husbandry activities there is a direct discharge of waste carried out to the river body which causes river quality to deteriorate. For the meeting point where the test site was established, the location of the flow from the sunagi body around the United Agricultural activities into a flow so the water conditions are not good. Apart from activities around the site, deteriorating water quality can also be seen both visually and in terms of odor, especially for streams on farms and meeting points.
On the basis of Table 2, it can be seen that at outlet 1 and outlet 2 the quality status meets the class I quality standards where the results obtained show pollutant index results $<1$ which means that the quality of the test site is still quite good or - in terms of the ecological status - it is in a condition not yet or slightly polluted (Sudarso et al. 2009). As for the location of agricultural waste, livestock farms and meeting points are under mildly polluted conditions. This is indicated by the results of the pollutant index calculation at a value of $>1$ but $<5$, as shown in Table 2 .

The evidence that all three locations are under mildly polluted conditions can be seen from the measurement value of the parameters as well as the physical appearance of the flow. Where one of the parameters with value above the class I water quality standard is the suspended residue that is at the class III quality standard threshold in the three locations, namely the location of agriculture, animal husbandry and the meeting point between the flow of agriculture and animal husbandry.

This is caused by the hue around the test point where at the point of agriculture there is a runoff from artificial irrigation (sprinkle irrigation) at that location. At the location of agricultural

Table 2. River quality status based on the pollutant index

\begin{tabular}{|c|c|c|c|c|}
\hline Point name & Max & Ave & IP & Status \\
\hline Outlet 1 & 0.82 & 0.29 & 0.5 & Meet quality standards \\
\hline Outlet 2 & 0.73 & 0.26 & 1.1 & Meet quality standards \\
\hline Agricultural waste & 1.57 & 0.59 & 1.1 & Lightly polluted \\
\hline Animal waste & 1.47 & 0.59 & 1.52 & Lightly polluted \\
\hline Meeting point & 2.06 & 0.59 & & \\
\hline
\end{tabular}


commodities grown in the form of horticultural commodities such as cabbage which has a planting period of 50-100 days, carrots that have a planting period of approximately 12 weeks or 84 days. Thus, during the retrieval period, the sample water is affected by the condition of tillage and irrigation around the river, as seen from the flow of water which tends to be more turbid. At the point of agricultural discharge the sediment texture is dominated by sand, followed by clay,

At the point of where a TSS farm has a sufficiently high value due to the direct discharge from cattle pens to the river flow at the test site, the activity causes the flow at this location tends to be more turbid and greenish in colour. At the point of animal exhaust, the sediment texture is dominated by sand, followed by clay.

In the TSS meeting point, it has a sufficiently high value because at this point two agricultural discharge streams and the flow from livestock discharge meet, the water situation visually looks turbid. At this point, in addition to the flow from agricultural and livestock waste is added to the flow from the household sewage that goes directly into the river. Thus, the TSS value is greatest among all test points. On the basis of their ecological status, the three locations are under a mildly polluted condition (Sudarso et al. 2009).

\section{Macrozoobenthos distribution}

The sampling of macrozoobenthos was carried out from the period July-September 2019. From these results, 28 types of macrozoobenthos were obtained. The diversity of macrozoobenthos in the test location was influenced by the physico-chemical characteristics and the surrounding environmental activities. The ten selected macrozoobenthos inclue: Sulcospira sp., Chironomous sp., Simullium sp., Hydropsyche sp., Palaemonetes sp., Libelulla sp., Corbicula sp. , Enallagma sp., Anentome sp. and Tubifex sp.

The macrozoobenthos parameter was chosen because of its considerable amount at each test point. However, each test point has one dominant parameter. For outlet points which are the output of the Pintu Air Danau both outlet 1 and outlet 2 are dominated by types Corbicula $s p$. where based on the results of the PCA biplot was strongly influenced by the parameters of dissolved oxygen, organic carbon and $\mathrm{N}$-total in sediment dominated by clay. This is caused by the Corbicula sp. need of substrate as food.
According to Juanedi (2010), Corbicula sp. is very dependent on the availability of feed in the habitat environment, this is in line with its abundance relationship with organic carbon parameters and the N-total value in the sediment which shows that at the location of its habitat there is quite a lot of food available.

According to Enri et al. (2010) that Corbicula $s p$. can live in both sandy and muddy habitats, this is in accordance with what was found in the field and can be seen in table 1, for outlet 1 and outlet 2 test points are different sedimentary conditions where for outlet 2 is dominated by clay which means that at this location the habitat conditions tend to be muddy. In turn, at the outlet 1 point the sediment is dominated by sand. This shows that the habitat is dominated by sand. In terms of abundance, Corbicula sp. can still live in both locations.

The abundance of Corbicula sp. is quite high due to the nature of life in groups. Endri et al. (2010) stated that there is a clustered nature of Corbicula $s p$. because of the habitat uniformity and it tends to cluster in the locations that have a lot of food.

For the point of agriculture it is dominated by Enallagma sp. which is the larvae of dragonflies. Enallagma $s p$. is influenced by the conditions of habitat depth, sediment in the form of clay, and the availability of P-total in the sediment. Figure 2 shows that the vector of Enallagma $s p$. is quite close to the clay and p-total parameters derived from surrounding agricultural activities. According to Corbet (1962), Enallagma sp. lives in riverbeds, and has the high tolerance ability.

For the macrozoobenthos the form Chironomous $s p$. dominate, which is closely related to TSS and nitrate parameters in sand sediments. According to Bouchard (2012) and McCafferty (1981) Chironomous sp. can live in various types of habitats, sediment dominated by mud, rocks or plant litter, because its tolerance value is moderate to high. Chironomus $s p$. is found in every water habitat from small seepage to large rivers and from temporary ponds to deep lakes, as well as in soft sediment, and on rocks. Several types of Chironomus sp. can survive with low dissolved oxygen. According to Muntalif et al. (2008) Chironomous sp. can live in locations with high organic values. This is consistent with the results of research in which Chironomous sp. has a close relationship with nitrate values. Sudarso and Wardiatno (2015) showed that Dipir chironomid larvae 


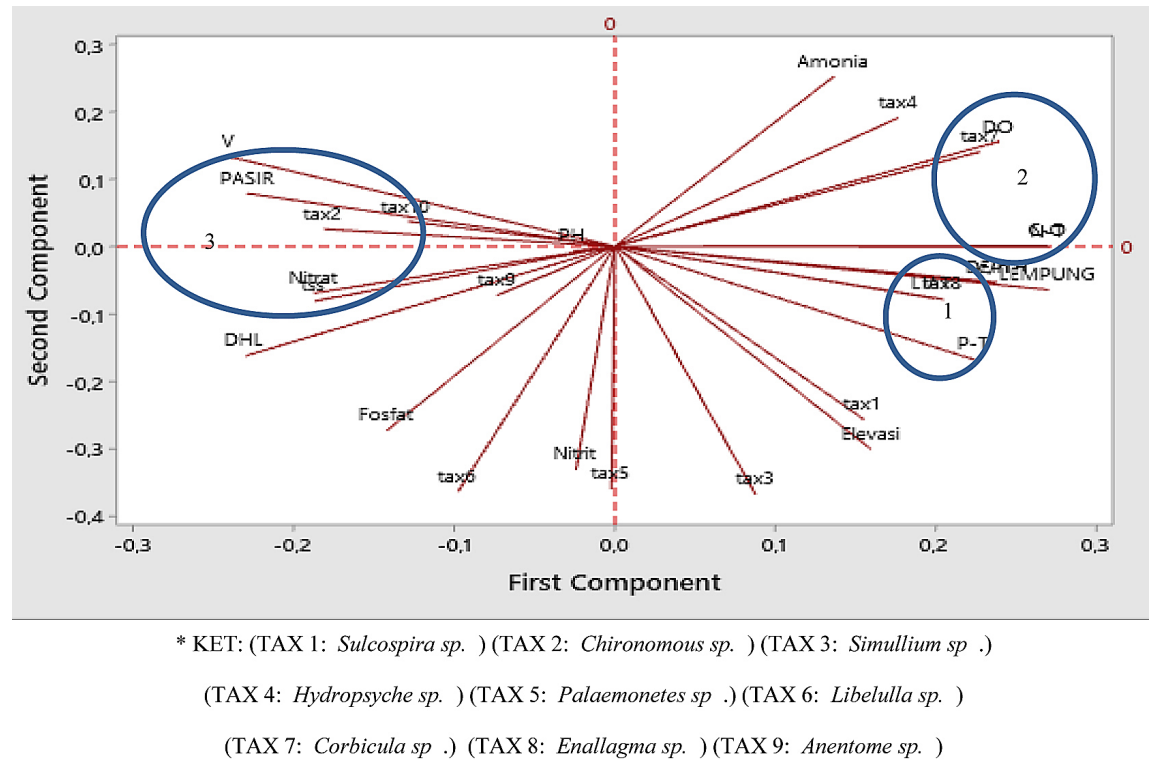

Figure 2. Biplot graph of physical-chemical parameters and dominant macrozoobenthos

were found in almost every habitat of the river that had not been disturbed until severe disruption. This shows that Chironomus sp. tolerant of organic pollution.

Besides Chironomous sp. there is also Tubifex sp., the existence of which is associated with TSS, nitrate parameters and it is found in the sandy habitat. Tubifex $s p$. in populations often indicates the magnitude of the disturbance caused by organic pollution (Sudarso and Wardiatno 2015). Tubifex sp. most commonly lives in lakes, ponds, marshes, and flow pools. Some species are found in swift watersheds. Tubifex $s p$. is most often found in soft sediments, but some can be found in coarse detritus, in vegetation, and in coarse substrates. Tubifex $s p$. can live in highly polluted waters with very low dissolved oxygen levels, very rich organically.

It can be seen that each macrozoobenthos parameter has a close relationship with key physical and chemical parameters, meaning that the environmental conditions have a major influence on the type and continuity of macrozoobenthos.

The overall results of the study indicate that based on the determination of the quality status with the method of pollutant index the location of the study is divided into the status that meets the quality standards and which is considereded mildly polluted. However, according to Sudarso and Wardiatno (2015), the determination of the status of water quality is assessed that meet the quality standards, which can be called slightly polluted, whereas in mild polluted conditions are stated in lightly polluted.
Table 3 shows that the parameters that have a strong relationship with the presence of acrozoobenthos consist of eight water and sediment parameters, which have a relationship to the four dominant types of macrozoobenthos at each test location with a certain range.

\section{CONCLUSION}

On the basis of the results of PCA, it can be seen that there are 10 macrozoobenthos that have a relationship with 16 physical and chemical parameters of their habitat environment. The results of the pollutant level matrix shows that Corbicula $s p$. becomes a bioindicator in slightly polluted water, and has a relationship of dissolved oxygen, organic carbon and N-O. Enallagma sp., Tubifex sp., and Chironomous sp. are bioindicator of mildly polluted water quality and have a relationship with the parameters of nitrate, TSS and P-total. The physico-chemical parameters and abundance of macrozoobenthos in the results of this study can be used as bioindicators of the river water quality which has a tropical climate and specific ecoregion conditions as the study location.

\section{Acknowledgements}

We would like to express a blessing and gratitude to the Bandung Institute of Technology which has supported the funding of this research through P3MI Activities. 
Table 3. Pollution level based on physico-chemical parameters and dominant macrozoobenthos

\begin{tabular}{|c|c|c|c|c|}
\hline \multirow{2}{*}{ Parameters } & \multirow{2}{*}{ Unit } & \multicolumn{2}{|c|}{ Pollution level } & \multirow{2}{*}{ References } \\
\hline & & slightly polluted & lightly polluted & \\
\hline $\mathrm{NO}_{3}$ & $\mathrm{mg} / \mathrm{L}$ & $<0.1$ & 1,10 & WHO (1996) \\
\hline DO & $\mathrm{mg} / \mathrm{L}$ & $6-8$ & $<6$ & WHO (1996) \\
\hline TSS & $\mathrm{mg} / \mathrm{L}$ & $<20$ & $20-100$ & Sudarso (2015) \\
\hline$(C=0)$ & $\%$ & $2-4$ & $<2$ & \\
\hline NT & $\%$ & $0.3-0.5$ & $<0.3$ & \\
\hline PT & $\%$ & $<1.5 \%$ & $1.5-1.8$ & \\
\hline Clay & $\%$ & $22-26$ & $<22$ & \\
\hline Sand & $\%$ & $5-65$ & $>65$ & \\
\hline Corbicula sp. & ind $/ \mathrm{m}^{2}$ & $101-800$ & $<101$ & \\
\hline Enallagma sp. & ind $/ \mathrm{m}^{2}$ & $<16$ & $16-34$ & \\
\hline Chironomous sp. & ind $/ \mathrm{m}^{2}$ & 0 & $1-800$ & \\
\hline Tubifex sp. & ind $/ \mathrm{m}^{2}$ & 0 & $1300 ?$ & \\
\hline
\end{tabular}

\section{REFERENCES}

1. Bahri S. 2007. Impact of organic waste on water quality in the upper Citarum River. Pusair Bulletin, 16 (46), 11-18.

2. Bahri S. and Irianto E.W. 2007. Integration of thematic maps and water quality indices for the study of river water quality. Pusair Bulletin, 16 (47).

3. Barbour M.T., Stribling J.B. and Karr J.R. 1995. Multimetric approaches for establishing biocriteria and measuring biological conditions. In: W.S. Davis and T.P. Simon (Ed.) Biological assessment and criteria: Tools for water resource planning and decision making. FL Lewis 6377, Boca Raton.

4. Chazanah N., Muntalif B., Sudjono P., Rahmayunita I. and Suantika G. 2018. Determinant parameters for upstream ecological status assessment of Citarum River, Indonesia. International Journal of GEOMATE.

5. Chazanah N., Sudjono P., Hasby F.A., Suantika G. and Muntalif B.S. 2017. Development of bioassessment tools for ecological status using macrozoobenthic communities in upstream areas (Case study: Citarum River, West Java, Indonesia). Journal of Water Resources and Protection, 9, 770-785.

6. Citarum River Basin Agency (BBWS), Citarum Region Water Resources Management Plan. Indonesia BBWS 2016, 3-27.

7. De Pauw N. and Vanhooren G. 1983. Method for biological quality assessments of watercourses in Belgium. Hydrobiology, 100, 153-168.

8. Effendi H. 2003. Water quality study for water resources and environmental management. Canisius Publishers, Yogyakarta.

9. Fore L.S., Karr J.R. and Conquest L.L. 1993. Statical properties of an index of biological integrity used to evaluate water resources. Can J Fish Aquat. Sci., 51, 1077-1087.
10. Goethals P. and De Pauw N. 2001. Development of a concept for integrated ecological river assessment in Flander, Belgium. J. Linol., 60, 7-166.

11. Kim H. and Montagna P.A. 2009. Implication of Colorado River (Texas, USA) freshwater inflow to benthic ecosystem dynamic: A modeling study. Estuarine, Coastal and Shelf Science, 83, 491-504.

12. Kramadibrata I. 1996. Animal ecology. Bandung: Department of Biology FMIPA ITB.

13. Kranzfelder P., Anderson A.M., Egan A.T., Mazack J.E., Bouchard R.W., Rufer M.M. and Ferrington L.C. 2015. Use of chironomidae (diptera) surfacefloating pupal exuviae as a rapid bioassessment protocol for water bodies. J. Vis. Exp., 101, e52558, $1-19$.

14. Kusumaningrum T.D. and Bahri S., 2008. Study of river water quality using macrozoobenthos organisms with the family biotic index method. Journal of Water Resources, 4(1), 75-87.

15. Li Y., Xu L. and Li S. 2009. Water quality analysis of the Songhua River basin using multivariate techniques. J. Water Resources and Protection, 2, 110-121.

16. Malensang J.S., Komalig H. and Hatidj D. 2012. Development of Multiple Polynomial Regression Models in Marketing Data Cases. Journal of Scientific Science, 12(2).

17. McCafferty W.P. and Provonsha A.V. 1983. Aquatic entomology. Jones and Bartlet Pulishers International, London.

18. Muntalif B.S., Ratnawati K., and Bahri S. 2008. Bioassessment using benthic macroinvertebrates for determination of upper Citarum River water quality. Purification Journal, 9 (1), 49-60.

19. Nybakken JW. 1992. Marine biology: An ecological approach. PT Gramedia, Jakarta.

20. Republic of Indonesia Government Regulation Number 82 Year 2001 regarding Management of Water Quality and Water Pollution Control. Jakarta. 
21. State Ministry of Environment. 2003. Decree of the Minister of Environment No. 115 of 2003 concerning Determination of Water Quality Status.

22. Sudarso Y. and Wardiatno Y. 2015. Assessment of river quality status with macrozoobentos indicators. Bandung, Pena Nusantara.

23. Sudarso Y., Suryono T., and Yoga G. 2009. Preparation of biocriteria using multimetric concepts. Case study of the cisadane creek. Indonesian Oceanology and Limnology, 35(2), 179-200.

24. UNESCO/WHO/UNEP 1992. Water quality assessments. A guide to use of biota, sediments, and water in environmental monitoring. World Health Organization: www.who.int/docstore/water_anitation_health/wqassess/ch1 0.htm.

25. Wardoyo 1975. Water Quality Management. Bogor (ID): Institut Pertanian Bogor.

26. Wilhm J. and Dorris T. 1968. Biological parameters for water quality criteria. Bioscience, 477-481.
27. Wilhm J.F. 1975. Biological indicator of pollution. In: Whitton B.A. (Ed.) River ecology. Blackwell Scientific Publications, Oxford, 370-402.

28. Wimbaningrum R., Indriyani S., Retnaningdyah C. and Arisoesilaningsih E. 2016. Monitoring water quality using biotic indicates of benthics macroinvertebrates along surfaces water ecosystems in some tourism areas in East Java Indonesia. Journal of Indonesian Tourism and Development Studies, 4(2), 81-90.

29. Zeybek M., Kalyoncu H., Caracas B. and Ozgul S. 2014. The use of BMWP and ASPT indices for evaluation of water quality according to macroinvertebrates in Degirmendere Stream (Ispata, Turkey). Turkish Journal of Zoology, 603-613.

30. Zulkifli H. and Setiawan D. 2011. Macrozoobentos Community Structure in the Sungzai Musi Waters of the Pulokerto Region as a Biomonitoring Instrument. Jurnal Natur Indonesia, 95-99. 